\title{
アンサンブルシミュレーションと 擬似温暖化手法による 特定の気象イベントの将来変化の推定 EVALUATION OF FUTURE VARIATIONS OF A PARTICULAR WEATHER EVENT BY ENSEMBLE-PSEUDO GLOBAL WARMING SIMULATION
}

\author{
谷口健司 1 \\ Kenji TANIGUCHI \\ 1正会員 博（工） 金沢大学理工研究域 環境デザイン学系 准教授（†920-1192 金沢市角間町）
}

\begin{abstract}
In a flood-control planning in Japan, a high-water level is estimated from selected target rainfall events. To draw up adaptive flood control measures for future climate change, information about possible maximum rainfall are indispensable. Climatological or statistical information about precipitation are not enough for that purpose. In this study, a method to evaluate future variations of a particular extreme weather event is developed by combining ensemble simulation and pseudo global warming method. Perturbations for ensemble members are generated from simulation results by Lagged Average Forecasting method. The perturbations are scaled up/down and added to the original conditions, and ensemble members are prepared. Ensemble technique enables to examine whether differences between the present and future simulations are caused by global warming or chaotic behaviors from perturbation. Probability density curves from ensemble results give clearer view of future variations of a weather event.
\end{abstract}

Key Words : climate change, numerical simulation, pseudo global warming method, ensemble simulation, tropical cyclone

\section{1. はじめに}

我が国の治水計画は対象降水の選定，流出解析，基本 高水の決定，計画高水流量の決定，という流れで整備目 標が決定される1)。対象降水の選定においては流域の重 要度等に応じて確率年が決定され，それに応じた過去の 気象事例が選定されるが，必要に応じて降水量等の引き 伸ばしが行われる．地球温暖化に関する研究が進展する 中, 将来における大雨の頻度増加やスーパー台風と呼ば れる従来の階級区分を上回る強さを持つ台風の発生等が 指摘されており ${ }^{2)}$ ，こうした気候変化下においては，過 去の降水観測データから算出される確率降雨による治水 計画では不十分となる可能性がある.

国土交通省は平成27年1月に「新たなステージに対応 した防災・減災のあり方」において，大規模水害への対 応等に関する取りまとめを公表したが，最大クラス洪水 の評価手法については明示されていない，一方，国交省 による「想定最大外力（洪水，内水）の設定に係る技術
検討会」では既往最大の降雨量と年超過確率 $1 / 1,000$ 程 度の降雨量を基に計画することが提案されている3)。し かし，気候変化下における極端事象が年超過確率

$1 / 1,000$ 程度の降雨量を上回り, 想定以上の外力が発生 する可能性もあり，そうした可能性を加味した治水計画 の策定のためには, 温暖化予測結果を有効に活用した計 画論の構築が不可欠と考えられる.

一方, 地球温暖化に関する影響評価研究により，平均 的な気候場の変化や豪雨の発生頻度等の変化に関寸る知 見は蓄積されてきたが，こうした情報は上述の治水計画 策定手法に直接活用寸ることは難しく, 特定の気象イ心゙ ントに基づく将来における極端な気象イベント時の降水 情報が不可欠である.

本研究では温暖化予測結果を活用した特定の気象イ心゙ ントの将来変化の可能性を評価する手法の構築を目的と し，2013年に発生した台風18号（T1318）を例に，数值 気象モデルを用いて，アンサンブルシミュレーションと 擬似温暖化手法を組み合わせた実験を行う。 


\section{2. 研究方法}

\section{（1）モデル及びデータ}

本研究ではシミュレーションを実施する数值気象モデ ルとして, 米国大気研究所を中心に開発が進められてい る非静力領域気象モデルであるWeather Research and Forecasting (WRF) 4)モデルを用いる.

WRFを用いた再現シミュレーションの初期值, 境界 条件には気象庁長期再解析デー夕（JRA55） 5)及び NOAA 1/4 degree SSTデータのを用いる. 後述する擬似温 暖化データの作成には気象庁気象研究所が開発した MRI-CGCM3, 及び東京大学・国立環境研究所・海洋研 究開発機構が開発したMIROC5, MIROC-ESMによる3つ の温暖化予測結果を用いる. なお，本研究では将来気候 として, 産業革命前と比較して今世紀末の放射強制力が $8.5 \mathrm{~W} / \mathrm{m}^{2}$ 上昇するRCP 8.5 シナリオによる温暖化予測結果 を用いる.

\section{（2）擬似温暖化データの作成}

本研究では擬似温暖化手法》により作成した大気場を 初期值・境界条件とした気象シミュレーションを行い, 特定の気象イベントの将来気候における变化の可能性に ついて検討寸る．擬似温暖化データは，全球気候モデル による現在気候と将来気候の間での変化量を, 現在気候 を精度よく再現したデータにアノマリとして加えて作成 する7. アノマリは2090～2100年の各月平均值と1990～ 2000年の各月平均值の差として作成する. アノマリを加 えて更新する変数は海面校正気圧, 気温, 地表面温度, 比湿, 風速, ジオポテンシャル高度, 海面水温である. なお，MRI-CGCM3，MIROC5及びMIROC-ESMの初期 時刻（2013年9月13日00UTC）における地上 $2 \mathrm{~m}$ 気温のア ノマリの対象領域（後述するシミュレーションの親領

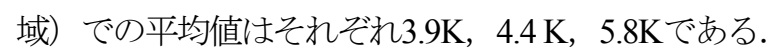

\section{（3） アンサンブルシミュレーションの実施}

本研究では将来気候における気像現象を評価するため, 上述の擬似温暖化手法により作成した大気場を初期值 ・ 境界条件とした気象シミュレーションを行う。擬似温暖 化手法は数值気象モデルによる力学的ダウンスケーリン グと合わせて用いられ，10〜数十年程度の期間を対象と して, 詳細な将来の気候情報の作成に用いられてきたが, 特定の気象イベントを対象とした研究にも用いられてい る8). しかし，特定の気象イベントに関して現在及び将 来気候について単一のシミュレーションを行うのみでは, 両者の違いが温暖化の影響によるものか, 両者の初期值 におけるわずかな差に基づくカオス的な挙動によるもの かの評価が困難である. Taniguchi and Sho $(2015)^{9}$ は は2000 年東海豪雨を対象として, ラグ平均予報法10)によるアン サンブルシミュレーションと擬似温暖化手法を組み合わ

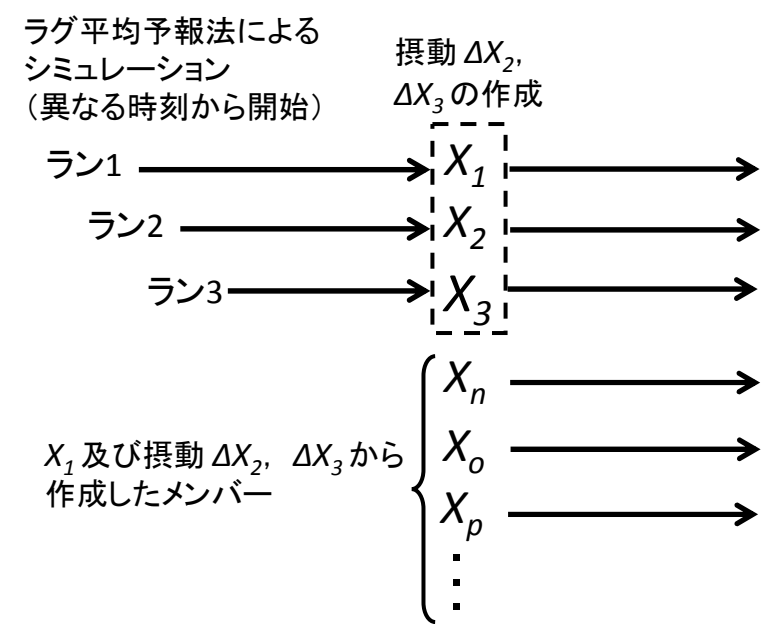

図-1 アンサンブルメンバー作成のイメージ.

表-1 摂動作成のためのラグ平均予報法を用いたシ ミュレーションの概要

\begin{tabular}{|c|c|c|c|}
\hline $\begin{array}{c}\text { 作成する } \\
\text { 状態 }\end{array}$ & 開始時刻 & $\begin{array}{c}\text { 湶動作成 } \\
\text { 時刻 }\end{array}$ & 終了時刻 \\
\cline { 1 - 2 }$X_{1}$ & $\begin{array}{c}\text { 9月13日 } \\
\text { 00UTC }\end{array}$ & & \\
\cline { 1 - 2 }$X_{2}$ & $\begin{array}{c}\text { 9月13日 } \\
\text { 06UTC }\end{array}$ & $\begin{array}{c}\text { 9月14日 } \\
\text { 00UTC }\end{array}$ & $\begin{array}{c}\text { 9月16日 } \\
\text { 12UTC }\end{array}$ \\
\cline { 1 - 2 }$X_{3}$ & $\begin{array}{c}\text { 9月13日 } \\
\text { 12UTC }\end{array}$ & & \\
\hline
\end{tabular}

せて現在及び将来気候について複数のシミュレーション を行い，両者の差がアンサンブル間の摂動に伴うものか， 温暖化の影響であるかについて評価した.

ラグ平均予報法は開始時刻をずらした複数のシミュ レーションを行う簡易なアンサンブル手法であるが，多 くのアンサンブルメンバーによるシミュレーションを実 行する場合には, シミュレーション時間に隔たりができ てしまい, 再現精度に差が生じたり, シミュレーション 時間が余分に長くなってしまう. アンサンブルシミュ レーションにおける初期摂動の作成方法のひとつである セルフブリーディング法では，コントロールランと摂動 を与えたランの差を初期摂動として活用寸る ${ }^{11)}$.

本研究ではこの手法を応用し, ラグ平均予報法により 小数のアンサンブルランを実行し，そのメンバー間での 差を基に摂動を発生させ，新たなアンサンブルメンバー を作成することとした．まず，3つの異なる時刻から WRFによるシミュレーションを開始し，ある時刻で中 断し, 各シミュレーションから状態 $X_{1}, X_{2}, X_{3}$ を得る. 次に, $X_{2}$ と $X_{1}$ の差による摂動 $\Delta X_{2}, X_{3}$ と $X_{1}$ の差による捸 動 $\Delta \boldsymbol{X}_{3}$ を作成する．これらから，任意の状態 $\boldsymbol{X}_{n}$ を以下の ように作成する（図-1）。

$$
X_{n}=X_{1}+\alpha \Delta X_{2}+\beta \Delta X_{3} \cdots(1)
$$

ここで， $\alpha$ 及び $\beta$ は $\Delta \boldsymbol{X}_{2}$ と $\Delta \boldsymbol{X}_{3}$ のスケールファクター とする， $\alpha, \beta$ を変化させることで， $\boldsymbol{X}_{1}, \quad \Delta \boldsymbol{X}_{2}, \quad \Delta \boldsymbol{X}_{3}$ か 
表-2 アンサンブルメンバ一作成時の摂動の スケールファクター $\alpha, \beta$ の組み合わせ

\begin{tabular}{|c||c||c||c|}
\hline$(\alpha, \beta)$ & $(\alpha, \beta)$ & $(\alpha, \beta)$ & $(\alpha, \beta)$ \\
\hline \hline$(-1 / 3,1 / 3)$ & $(0,2 / 3)$ & $(1 / 3,2 / 3)$ & $(2 / 3,1 / 3)$ \\
\hline$(-1 / 3,2 / 3)$ & $(1 / 3,-1 / 3)$ & $(1 / 3,1)$ & $(2 / 3,2 / 3)$ \\
\hline$(-1 / 3,1)$ & $(1 / 3,0)$ & $(2 / 3,-1 / 3)$ & $(1,-1 / 3)$ \\
\hline$(0,1 / 3)$ & $(1 / 3,1 / 3)$ & $(2 / 3,0)$ & $(1,1 / 3)$ \\
\hline
\end{tabular}

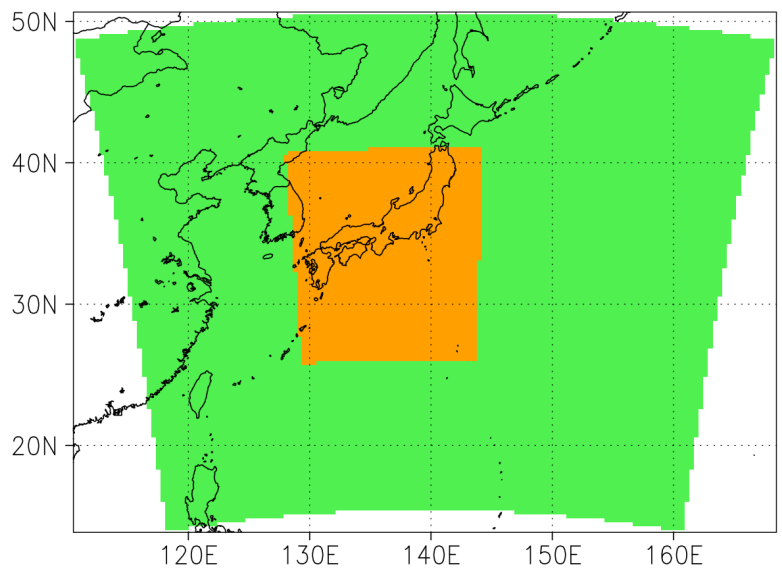

図-2 WRFによるシミュレーション領域．緑が親領

域，橙色が子領域を現す。

表-3 WRFにおける各種設定等

\begin{tabular}{|l|l|}
\hline モデルバージョン & 3.5 .1 \\
\hline 空間解像度 & $30 \mathrm{~km}$ (親領域), 10km(子領域) \\
\hline 積分間隔 & 120 秒(親領域), 40秒(子領域) \\
\hline 雲微物理スキーム & New Thompson scheme \\
\hline 積雲対流スキーム & Grell-Freitas scheme \\
\hline 放射スキーム & CAM scheme \\
\hline 地表面スキーム & Mellor-Yamada-Nakanishi-Niino \\
\hline 陸面モデル & Noah Land Surface Model \\
\hline 境界層 & Mellor-Yamada-Nakanishi-Niino 2.5 \\
\hline データ同化 & $\begin{array}{l}\text { スペクトルナッジング } \\
\text { (親領域のみ) }\end{array}$ \\
\hline
\end{tabular}

ら様々な状態 $\boldsymbol{X}_{\boldsymbol{n}}$ が作成ができる，本研究では，ラグ平均 予報法により表-1に示寸3つのアンサンブルランを実施 した後，同じく表-1に示した摂動作成時刻において，式 (1)により新たなアンサンブルメンバーを作成したのち, シミュレーションを再開する。ここでは，1/3を単位と して $(\alpha, \beta)$ を表-2のように変化させ， $\boldsymbol{X}_{1} \sim \boldsymbol{X}_{3}$ の周 辺に新たに16個のアンサンブルメンバーを作成し， $X_{1}$ 〜 X 3 と合わせて, 計19個のアンサンブルシミュレー ションを実施する。なお， JRA55を初期值・境界条件 とした再現実験のアンサンブルをCTL-Ens, MRICGCM3，MIROC5及びMIROC-ESMから作成したアノマ リを与えた擬似温暖化結果によるものをMRI-Ens, MIROC-Ens， ESM-Ensと標記する.

シミュレーションは2段階ネスティングを適用して行 うこととし，親領域はユーラシア東部から太平洋西部を 含む領域，子領域は本州全域及び九州地方を含む領域と する（図-2）。各領域の空間解像度は30km，10km とす

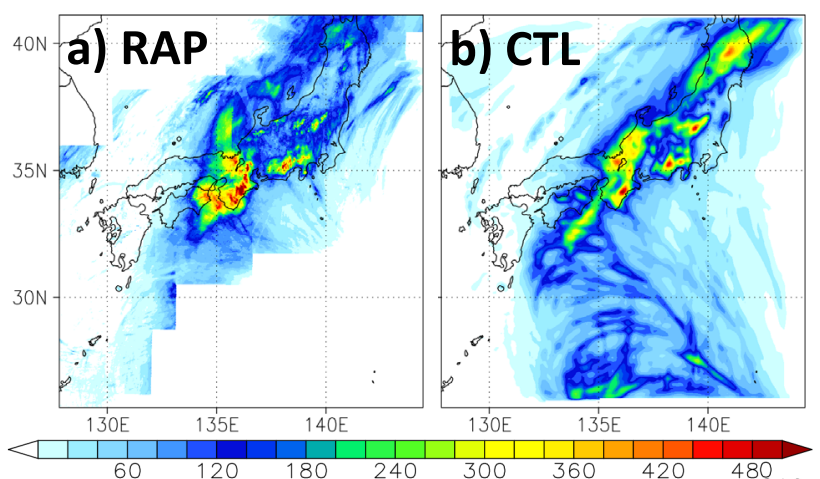

図-3 2013年9月13日00UTC〜9月16日12UTCまでの総 降水量分布 $(\mathrm{mm})$. (上段) レーダアメダス 解析雨量, (下段) CTL-Ensのうち9月13日 OOUTCから開始したシミュレーションの結果.

る. また，WRFにおける各種設定を表-3に示す.

\section{3. 再現シミュレーションの結果}

図-3は，CTL-Ensのうち，ラグ平均予報法による3つ のシミュレーションのひとつである2013年9月13日 00UTCから開始したものと，レーダアメダス解析雨量

（RAP）による9月13日00UTCから9月16日12UTCまでの 総降水量である. RAPにおいて紀伊半島から日本海側及 び静岡県から神奈川県周辺に広がる雨域については，シ ミュレーション結果においても再現されている．総降水 量については地域ごとに差が見られるが，紀伊半島及び 静岡県における大雨は再現されている。一方，関東北部 及び東北地方では降水が過大となっている.

図-4aは気象庁によるT1318の経路と，CTL-Ensの各メ ンバーにおける3 時間毎の最低気圧を与えた格子点から 推定した経路を示したものである．海上から愛知県沖に いたる経路では比較的類似した経路をたどっているが, 上陸後の経路についてはメンバー間でのばらつきが大き く，実際に比べてやや東よりの経路をたどっている.

総降水量, 台風の経路ともに観測結果との差がみられ るが，概祆 1318 の特徵は捉えているものと考えられる.

\section{4. 将来気候における台風特性の変化}

\section{（1）台風経路及び中心気圧}

各擬似温暖化結果に基づくアンサンブルシミュレー ションの結果を図-4b〜dに示す．いずれの結果において も三重県沖から関東地方沿岸あたりで経路がとぎれてい る. これは，3つの将来気候における台風の移動速度が 実際の結果及びCTL-Ensに比べて小さかったためである. MRI-Ens及びMIROC-ESMでは実際と近い経路をたどっ ているが，MIROC-Ensについては経路が西側に寄ってお 

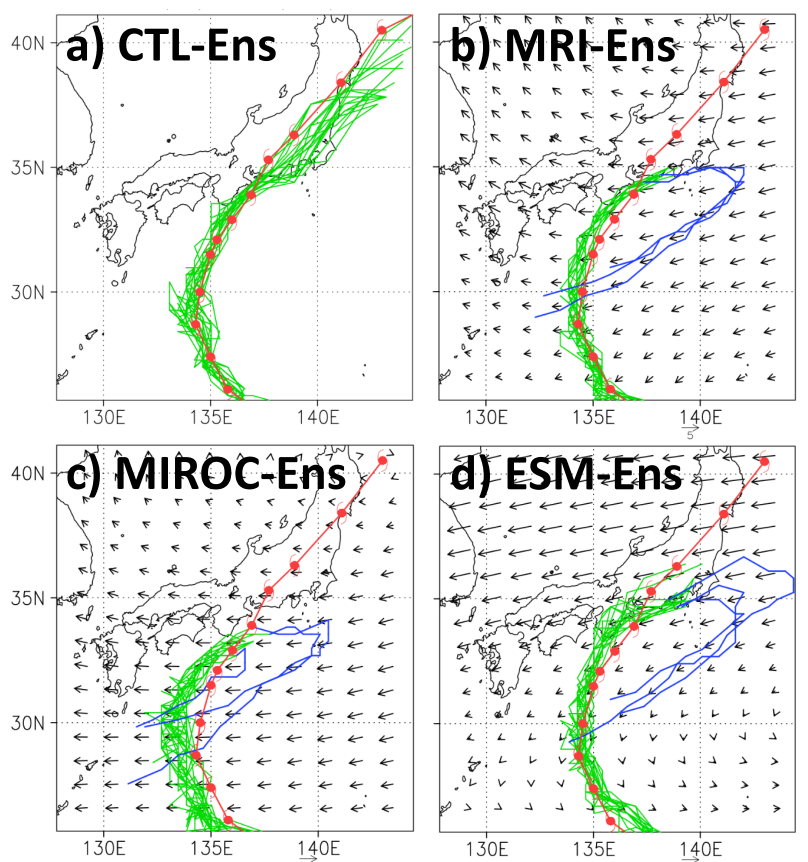

図-4 各アンサンブルシミュレーションにおける3 時間ごとの最低気圧から推定した台風経路 （緑）と気象庁によるT1318の経路（赤）, 及 びシミュレーション期間を9月18日18UTCまで 延長したラグ平均予報法による3つのケースで の経路（青）。ベクトルは擬似温暖化データ 作成の際に与えた500hPa面での風の偏差.

り，経路ごとのばらつきもやや大きい，一方，ラグ平均 予報法による3つのケースについて計算期間を9月18日 18UTCまで延長した結果, 将来気候ではやや東進した後 西進する様子がみられた。 また，これら3つのケースの 平均中心気圧（図-5）をみると，将来気候では9月16日 12UTC頃から中心気圧が高くなり，台風の勢力が弱まっ たのち西進していることがわかる.

擬似温暖化データ作成の際に与えた $500 \mathrm{hPa}$ 面の風のア ノマリ（図-4b〜d）をみると，いずれの将来気候におい ても西向きの偏差がみられ，一般流の変化により台風の 経路変化や移動速度の低下が生じたものと考えられる.

\section{（2）総降水量分布}

図-6はWRFによる子領域における各将来気候アンサ ンブルとCTL-Ensの平均総降水量の差である. 図-4に示 したように3つの将来気候アンサンブルにおいては台風 の進行が遅かったため，2013年9月16日12UTCまでの総 降水量は，特に関東北部から東北地方にかけて顕著な減 少がみられる。 また，シミュレーション期間を延長した 場合にも，台風が弱まり西進したため同地域での降水減 少が見られた（図は略）。MRI-Ensにおいては海洋上及 び東海地方の周辺で増加している一方，関西から北陸地 方で咸少している. MIROC-Ensについては他の2つの将 来気候アンサンブルに比べて経路がやや西よりになった ためか，経路の西側領域で顕著な降水増加がみられる.

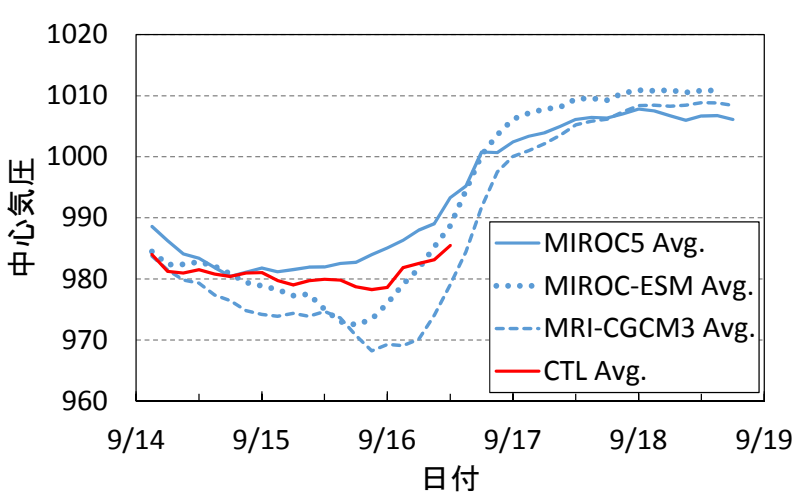

図-5 各アンサンブルシミュレーションにおけるラ グ平均予報法による3つのケースの平均中心気 圧. 将来気候についてはシミュレーション期 間を9月18日18UTCまで延長した結果.
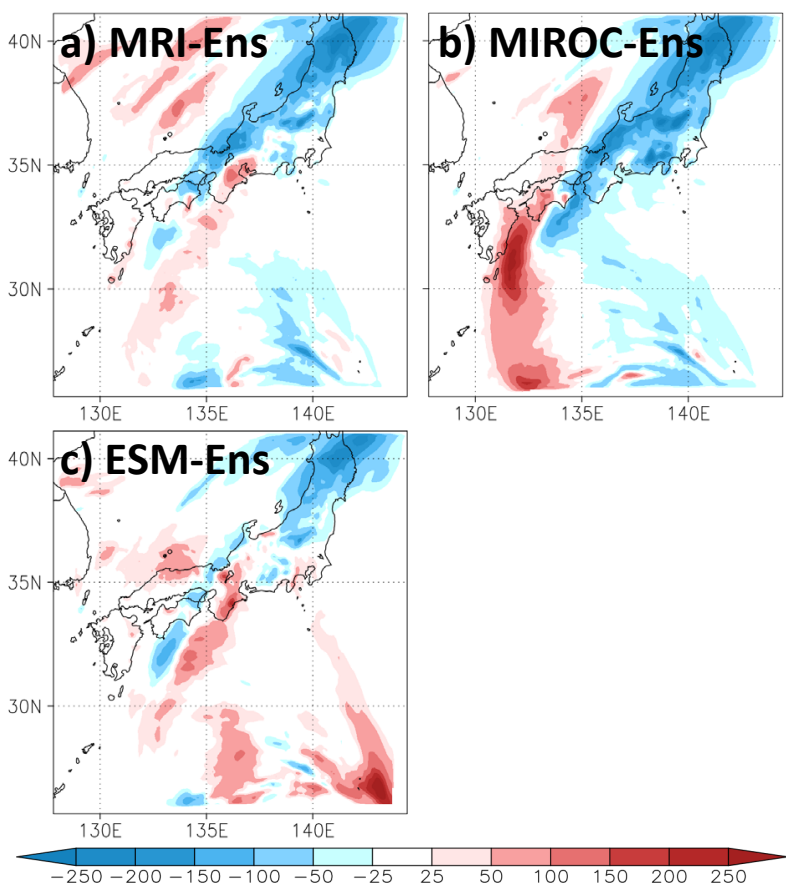

図-6 各将来気候アンサンブルシミュレーションに おける総降水量の平均値とCTL-Ens との差 (mm)．赤色が将来気候において増加，青色 が減少を表す。

一方，四国・関西以北については顕著な減少がみられる。 ESM-Ensでは，MRI-Ens と同様，海洋上から東海地方で 増加しており, 増加量もMRI-Ensよりやや大きい. 四国 沖でやや減少しているが，これは降水域の移動に伴うも のと考えられる.

\section{（3）最大総降水量及び最大時間降水量}

図-7は各シミュレーションにおける陸域での総降水量 の最大值及び時間降水量の最大值を抽出しプロットした ものである. 各アンサンブルについては平均值も示した.

MRI-Ensは最大総降水量, 最大時間降水量ともに平均 值はCTL-Ensに比べてやや大きくなっているが，両アン サンブルにおいて多くのメンバーで分布範囲が重複して 


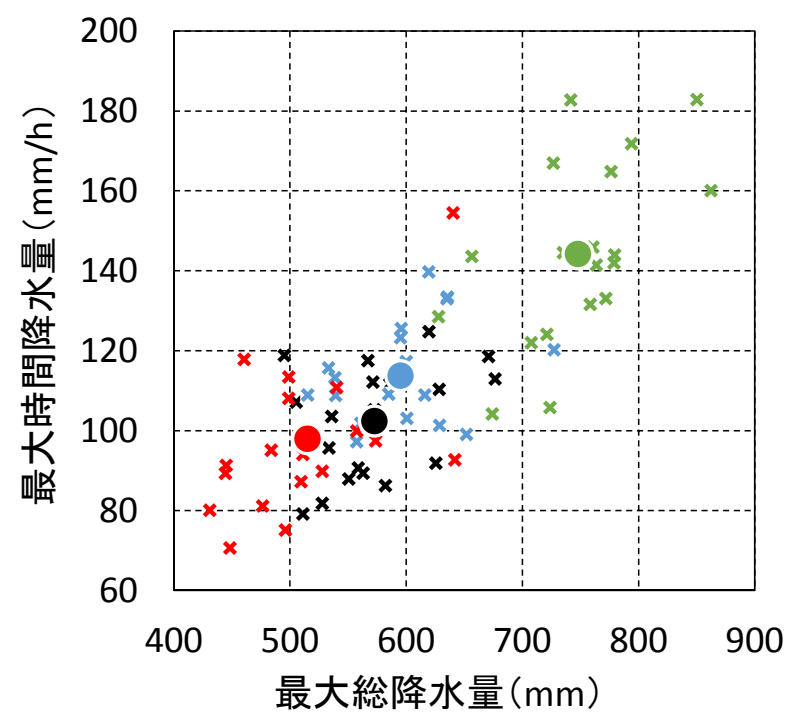

$\begin{array}{ll}* \text { CTL_Ens } & * \text { MRI_Ens } \\ \times \text { MIROC_Ens } & * \text { ESM_Ens } \\ - \text { CTL_Ens 平均値 } & \bullet \text { MRI_Ens 平均值 } \\ \text { - MIROC_Ens 平均值 } & - \text { ESM_Ens 平均値 }\end{array}$

図-7 各アンサンブルシミュレーションにおける陸 域での最大総降水量と最大時間降水量の散布 図. 各メンバーによる結果と平均値を示す.

いる. 一方, MIROC-EnsではCTL-Ensに比べて最大総降 水量, 最大時間降水量ともに小さくなっている. ただし, MIROC-Ensについては図-4にみたように台風経路が大き く変化しているため，比較には注意が必要である. ESM-Ensでは最大総降水量, 最大時間降水量の平均值と もに顕著な増加がみられる，また，各最小值がCTL-Ens の最大值付近に分布している.

図-8は陸域での最大総降水量別の発生頻度と, それが 正規分布に従うと仮定して求めた確率密度分布である.

図-7の結果から想定されるようにMRI-Ens とCTL-Ensの 確率分布の差は小さい. MIROC-Ensではやや小さい方に 分布がシフトしている. ESM-Ensは分布曲線のCTL-Ens からのずれが大きく，重複する範囲も小さい．重複部分 はアンサンブルメンバー間の摂動によりいずれの気候下 においても生じ得るが，重複していない範囲については 温暖化の影響によるものと捉えることができる. ESMEnsについていえば，現在気候で生じ得ない程度の大雨 が将来気候においては起こり得ることを示唆している.

図-9は最大時間降水量別の発生頻度と, それが正規分 布に従うと仮定して求めた確率密度分布である. MRIEnsの分布曲線の形状はCTL-Ensに類似しているが，や や大きくなる傾向がある. MIROC-Ensではメンバー間で の最大時間降水量のばらつきが大きいため, 分布範囲も CTL-Ensに比べてやや広くなっているが，ピークの出現 はCTL-Ens と同程度の位置にみられる. ESM-Ensについ てもメンバー間での最大時間降水量のばらつきが大きい ため分布範囲も広くなっている. また, CTL-Ensから大

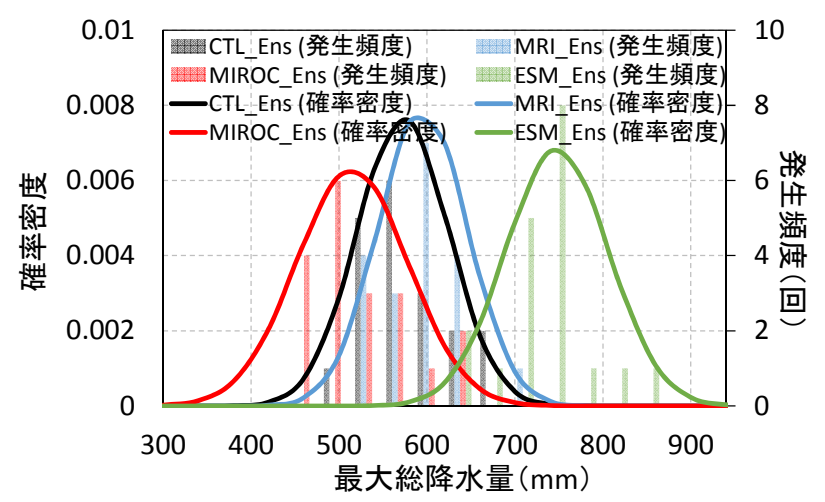

図-8 各アンサンブルシミュレーションの陸域での 最大総降水量の確率密度分布と発生頻度.

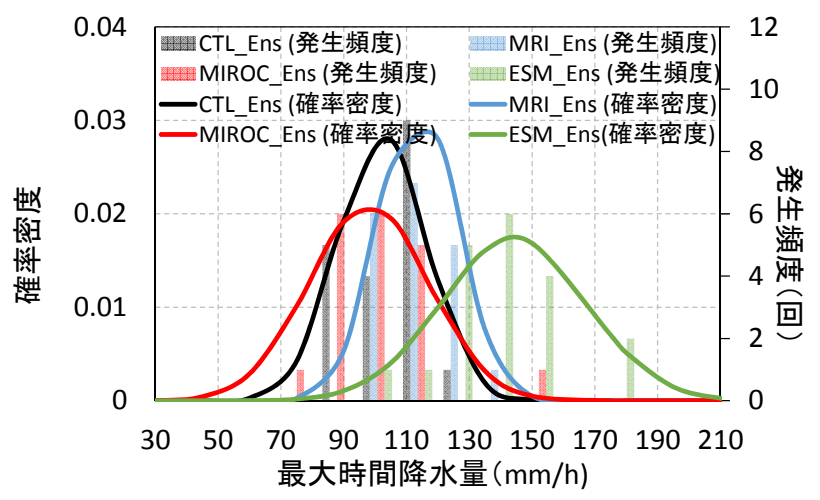

図-9 各アンサンブルシミュレーションの陸域での

最大時間降水量の確率密度分布と発生頻度.

きくずれており，重複も少ない，ESM-Ensで予測される ような気候となった場合には，温暖化の影響で台風特性 が極端に変化し得ることを示唆している.

\section{（4）最大風速の分布}

台風に伴う強い風は高波や高潮の原因ともなり, 沿岸 域の低平地では浸水被害の原因となり得るものである. 図-10はCTL-Ensのメンバー間で平均した最大風速の分 布及び，それらの各将来気候アンサンブルにおける值と の差を示したものである. 最大風速の差については図-4 に示した経路も合わせて示してある.

CTL-Ensでは台風の経路に沿って風の強い領域が広 がっている. MRI-Ens及びMIROC-Ensについては台風の 移動速度が遅いことや, 経路の違いのために東北地方の 沿岸域で最大風速が小さくなっているが, 各将来気候の 経路の周辺で風が強まっている. ESM-Ensにおいても, 経路上で最大風速が強くなっており, 将来気候において は台風に伴う風が強まる可能性は高いと考えられる.

\section{5. まとめ}

本研究では2013年に発生した台風18号を例として，擬 似温暖化手法と数值気象モデルによるアンサンブルシ ミュレーションを組み合わせることにより，特定の気象 イベントの将来気候における変化を検討した. 


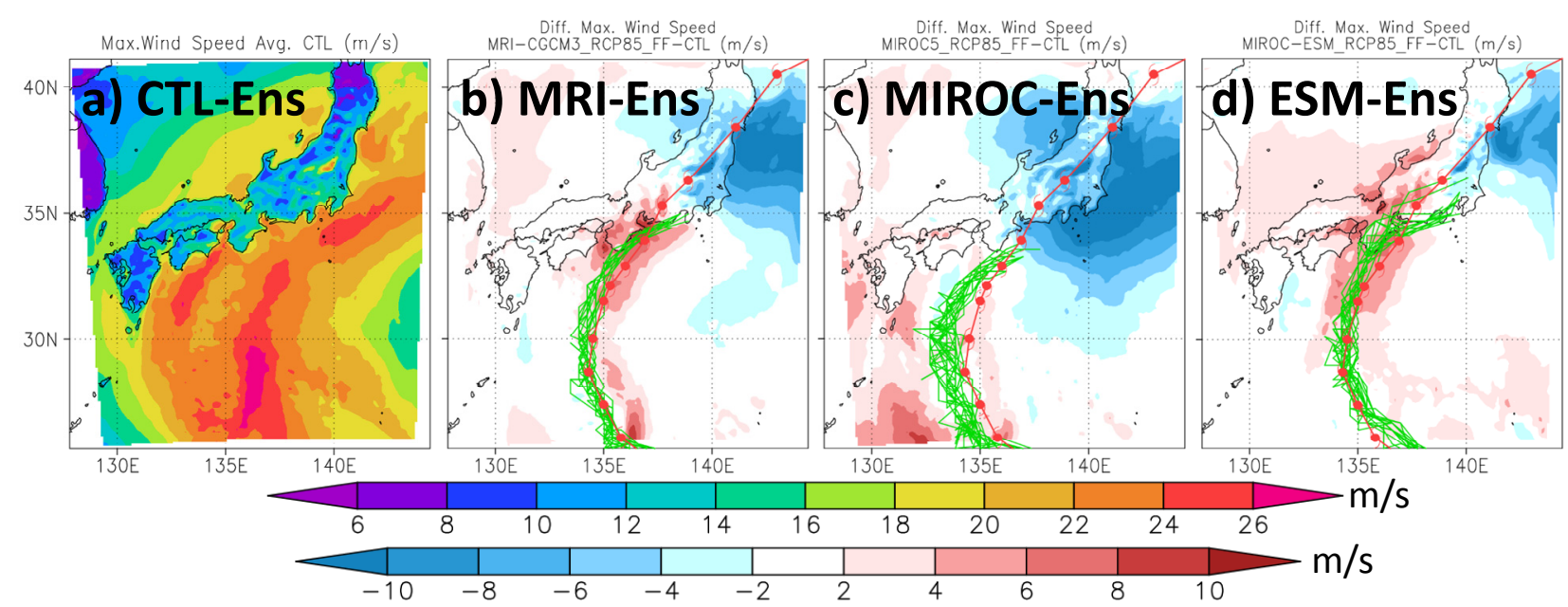

図-10 a) CTL-Ensの期間最大風速のメンバ一間の平均值の分布, b) d) その各将来気候アンサンブルの平均 值とCTL-Ensとの差. 赤色が将来気候において増加，青色が減少を表す．単位はいずれもm/s.

将来において太平洋上でT1318 と類似した台風が発生 した際の降水分布の変化は，擬似温暖化結果の間でばら つきがあり，これは経路にも大きく依存している．本手 法を活用し，実際に発生した気象イベントと類似の気象 場が将来気候において形成された場合に特定の流域での 洪水流出の変化を検討する際などには，降水分布が元の イベントと大きく異なる結果等については検討対象から 除外する必要も生じ得ると考えられる.

また，アンサンブルシミュレーションから求められる 確率密度分布により, 将来気候に関寸るシミュレーショ ンにおいて生じた変化が温暖化に起因するものか, 摂動 により現在気候においても生じ得るものかを推定できる とともに, 将来気候において発生確率が高い降水量等を 推定することが可能であり，治水計画や温暖化適応策策 定に有用な情報としての活用が期待される. 本研究では 3つの擬似温暖化結果の間で傾向に大きな差がみられた が，多くの温暖化予測モデルや複数の温暖化シナリオに よる結果を活用することにより，不確実性を考慮しつつ， 発生し得る結果を幅広く評価することが可能となる．本 研究では確率密度分布を求める際に正規分布を仮定した が，個別の適用においては最適な分布関数の検討も不可 欠と考えられる.

本研究では降水及び風速の変化について示したが，そ れらを入力データとした流出解析や波浪推算を実施する ことにより, 将来において類似の気象現象が生じた際の 河川流量の変化の可能性や，高波及び高潮の評価が可能 となる. 今後，そうした展開と計画論への応用の方法に ついて検討寸る必要がある.

謝辞 : 利用したデータセットは気象庁 55 年長期再解析 (JRA-55) プロジェクトにより作成されたものであり, 国家基幹技術「海洋地球観測探査システム」: データ統 合・解析システム(DIAS)の枠組みの下で収集・提供され たものである.

\section{参考文献}

1) 国土交通省河川局: 国土交通省河川砂防技術基淮同解説 計 画編，技報堂出版， 2008.

2) 気像庁訳: 気候変動に関する政府間パネル 第5次評価報告書 第1作業部会報告書 政策決定者向け要約, 2015.

3) 国土交通省水管理・国土保全局河川計画課河川計画課河川計 画調整室, 下水道部流域管理官 : 想定最大外力（洪水, 内 水）の設定について, 河川, No.828, pp.10-13， 2015.

4) Skamarock, W. C., J. B. Klemp, J. Dudhia, D. O. Gill, D. M. Barker, M. G. Duda, X.-Y. Huang, W. Wang, and J. G. Powers: A description of the advanced research WRF version 3. NCAR Technical Note, NCAR/TN-475+STR, 2008.

5) Kobayashi, S., Y. Ota, Y. Harada, A. Ebita, M. Moriya, H. Onoda, K. Onogi, H. Kamahori, C. Kobayashi, H. Endo, K. Miyaoka, and K. Takahashi: The JRA-55 Reanalysis: General Specifications and Basic Characteristics. J. Meteor. Soc. Japan, Vol.93, pp.5-48, doi:10.2151/jmsj.2015-001, 2015.

6) Reynolds, R. W., T. M. Smith, C. Liu, D. B. Chelton, K. S. Casey and M. G. Schlax: Daily High-resolution Blended Analyses for sea surface temperature. J. Climate, 20, pp. 5473-5496, 2007.

7) 佐藤智徳 : 擬似温暖化実験, 天気, 2010.

8) Hill, K. A. and Lackmann G. M.: The impact of future climate change on TC intensity and structure: A downscaling approach, J. Clim., Vol. 24, pp.4644-4661, 2011.

9) Taniguchi K. and Sho K.: Application of the pseudo global warming dynamic downscaling method to the Tokai Heavy Rain in 2000, J. Meteor. Soc. Japan, Vol.93, pp.551-570, 2015.

10) Hoffman R. N. and E. Kalnay: Lagged average forecasting, an alternative to Monte Carlo forecasting, Tellus A, Vol. 35, pp.110118,1983 .

11）気像庁予報部：アンサンブル技術の短期・中期予報への利 用〜激しい気象現象の予測向上を目指して〜, 気象業務支援 センター, 2006. 